\section{Grafting Fraser Fir onto Rootstocks of Selected Abies Species}

\author{
Eric Hinesley ${ }^{1}$ \\ Department of Horticultural Science, Box 7609, North Carolina State \\ University, Raleigh, NC 27695-7609
}

John Frampton ${ }^{2}$

Department of Forestry, North Carolina State University, Box 8002, Raleigh, NC 27695-8002

\section{Additional index words. Christmas trees, Phytophthora cinnamomi, root rot}

\begin{abstract}
Orthotropic shoots (tips of primary axes) from 3-year-old Fraser fir seedlings [Abies fraseri (Pursh) Poir.] were grafted onto rootstocks of Fraser fir, Korean fir (A. koreana Wils.), momi fir (A. firma Sieb. \& Zucc.), Nordmann fir (A. nordmanniana (Steven) Spach.), Turkish fir (A. bornmuelleriana Mattf.), and West Virginia balsam fir from Canaan Valley (Canaan fir) [A. balsamea (L.) Mill. var. phanerolepis Fern.]. Firstyear survival in the greenhouse was $92 \%$ to $98 \%$ except for momi fir $(83 \%)$. The percentage of grafted plants with orthotropic shoots was $92 \%$ to $98 \%$, except for Korean $(81 \%)$ and momi fir $(\mathbf{8 6} \%)$. Plants were subsequently established in replicated field experiments on three sites in the piedmont and mountains of North Carolina. In general, leader elongation of grafted Fraser fir scions was greater than leader growth on nongrafted transplants, including Fraser fir. Differences in survival appear to reflect interspecific variation in resistance to phytophthora root rot and/or tolerance of warm environments. Grafting may offer the potential to grow Abies Christmas trees on previously unsuitable sites, or to reclaim or continue using sites already seriously impacted by root rot.
\end{abstract}

Fraser fir (Abies fraseri) is an important Christmas tree species in the United States. It is native to higher elevations of mountains in western North Carolina, eastern Tennessee and southwestern Virginia. Most cultivated Christmas tree plantations in North Carolina occur at elevations of 900-1400 m, well below elevations of natural stands (Thor et al., 1962; Torbert and Nichols, 1991).

Recently, two problems have aroused interest in grafting Fraser fir onto rootstocks of other Abies species. First, phytophthora root rot (caused by Phytophthora cinnamomi Rands.), has become more prevalent on some Fraser fir sites (Benson and Grand, 2000). Once present, it often damages or destroys a significant portion of the stand, sometimes leading to abandonment of fields which would otherwise be good sites for Christmas trees. The ability to graft Fraser fir scions onto resistant rootstocks might allow continued use of infested sites, or reduce the likelihood that the disease might develop. Momi fir (A.firma) and Turkish fir (A. bornmuelleriana) are good

\footnotetext{
Received for publication 31 July 2001. Accepted for publication $2 \mathrm{Jan}$. 2002. This research was funded in part by the North Carolina Agricultural Research Service (NCARS), Raleigh, NC 27695-7643. Mention of trade names is neither an endorsement by NCARS nor criticism of similar unnamed products. Special thanks are extended to Dr. Steve McKeand for advice and assistance in grafting, and manuscript review. We also thank Anne Margaret Braham, Chris Hunt, Della Tucker-Riley, and Scott Smith for technical support.

${ }^{1}$ Professor.

${ }^{2}$ Associate Professor.
}

candidates, as well as Korean fir (A. koreana), Nordmann fir (A. nordmanniana), and West Virginia balsam fir from Canaan Valley (Canaan fir, A. balsamea var. phanerolepis) (Benson et al., 1998a, 1998b; Hinesley et al., 2000). Among these species, all except momi fir make good Christmas trees. Momi fir has stiff, sharp, prickly needles, and a light green color, but appears to have the most resistance to root rot.

A second motive for grafting Fraser fir onto other rootstock species is interest in finding or developing Abies species for Christmas tree production on warmer, lower elevation sites where Abies species, particularly Fraser fir, do not currently survive or grow in commercial plantings. Experience suggests that momi fir and Nordmann fir might be adaptable in the piedmont and coastal plain of North Carolina. Canaan, Korean, Nordmann, and Turkish fir are also likely candidates. To succeed at lower elevations, a species must tolerate climate and soils considerably warmer than in the mountains. Resistance to phytophthora root rot likely also plays an important role. The pathogen is favored by soil temperatures higher than optimum for growth of Fraser fir (Hinesley, 1981; Reynolds et al., 1985).

Abies species are relatively easy to graft (Tompkins, 1989; Williams, 1995). The North Carolina Forest Service routinely grafts onto to 5-year-old Fraser fir transplants, with at least $95 \%$ success. Preliminary grafts of Fraser fir onto momi fir have worked, but some grafts developed symptoms of incompatibility (Hinesley, unpublished). Our objective was to determine the feasibility of grafting Fraser fir onto rootstocks of Canaan, Fraser, Korean, momi, Nordmann, and Turkish fir for potential use as Christmas trees, especially on sites unsuitable for Fraser fir.

\section{Materials and Methods}

Rootstocks. Seedlings of Canaan, Fraser, Nordmann, Korean, and Turkish fir (provenances unknown) were purchased as 1-0 tubelings in mid-Apr. 1997. They were replanted into Ray Leach Super Cells ${ }^{\mathrm{TM}}$ (volume $=164 \mathrm{~cm}^{3}$ ) (Stuewe \& Sons, Corvallis, Ore.), using a composted pine bark substrate, and maintained under $50 \%$ shade lath throughout 1997 and early 1998. In May 1998, plants were transferred into larger containers $(7 \times 7 \times 23$ $\mathrm{cm}$, deep tree planting bands) (Anderson Die \& Mfg. Co., Portland, Ore.), using composted pine bark substrate, and were placed into a greenhouse where they remained during 1998 and 1999.

Owing to problems with the watering system, many Fraser firs died or were injured during fall and winter 1997-98. To ensure healthy plants for the grafting experiment in spring of 1999, 300 bare-root Fraser firs (3 years as a seedling, 1 year as a transplant) were dug from a western North Carolina nursery in early Sept. 1998. They were similar in height to the original containerized plants, but had slightly larger stem caliper. Transplants were planted into Anderson planting bands $(7 \times 7 \times$ $23 \mathrm{~cm}$ ), using composted pine bark, and placed into the greenhouse. Fraser fir produces much of its root growth in the fall, so planting in August or early September allows plants to become well established prior to winter (Hinesley, 1985). Plants of all species were overwintered in a greenhouse set at a minimum of $2{ }^{\circ} \mathrm{C}$.

Momi fir seedlings were not available in the original acquisition of plants. Seedlings from nearby experiments-grown in Ray Leach Pine Cells ${ }^{\mathrm{TM}}$ (volume $=66 \mathrm{~cm}^{3}$ )-were transplanted into 0.95-L pots in Spring 1998, and maintained in the greenhouse with the other species.

Plants received a complete water soluble fertilizer [Peters 15-16-17 Peat Lite Special; The Scotts Co., Marysville, Ohio)] weekly at an $\mathrm{N}$ rate of $150-200 \mathrm{mg} \cdot \mathrm{L}^{-1}$, and were watered as needed, usually two or three times per week. August through October, the daily photoperiod was extended to 16 -h with $1000-\mathrm{W}$ halide lamps $1.5 \mathrm{~m}$ above the seedlings and at a $3 \times 3$-m spacing. Gnatrol (Abbot Lab. Chem. and Agr. Prod. Div., North Chicago, Ill.), Merit (Bayer Corp., Kansas City, Mo. ), and Asana (Dupont Corp., Wilmington, Del. ) were used as needed to control fungus gnats (Bradysia sp.) and other insect pests. Banrot (Scotts-Sierra Protection Co., Marysville, Ohio ) was applied as needed to prevent gray mold (Botrytis cinerea Pers.:Fr.) on succulent new growth. Lateral branches were pruned, but not removed completely, on the larger plants, especially Canaan and Korean fir, to improve air flow and reduce the amount of tightly packed, succulent new growth.

Scion material. On 18 Mar. 1999, terminal shoots (tips of primary axes) were collected 
from 1100 large 3-year-old Fraser fir seedlings (source: Roan Mt., N.C.) at the Linville River Nursery (N.C. Forest Service) in Crossnore. Shoots averaged about $15 \mathrm{~cm}$ long and 4 to $5 \mathrm{~mm}$ in diameter. They were sealed in plastic bags, stored on ice, transported to Raleigh, and placed into a $0{ }^{\circ} \mathrm{C}$ cold room.

Grafting. Grafting was carried out 19-24 Mar. 1999. Buds were swelling and beginning to break when grafting was initiated 19 Apr. 1999.

Cleft grafts (Hartman et al., 1990) were made by clipping out the terminal bud cluster on the leader (primary axis), and making a vertical cut (parallel to stem axis) 2 to $3 \mathrm{~cm}$ long in the middle of the stem, using a sharp, clean grafting knife. Fraser fir scions of similar diameter were shortened to 6 to $8 \mathrm{~cm}$, and cut with a grafting knife to gradually taper on the lower $2-3 \mathrm{~cm}$. Scions were inserted into the vertical slit previously made in the terminal, taking care to match rootstock and scion cambia on at least one side of the graft. Graft unions were wrapped with either a grafting rubber or Parafilm ${ }^{\mathrm{TM}}$ strips $(1 \mathrm{~cm}$ wide $\times 5$ to $10 \mathrm{~cm}$ long), and coated with hot wax. The number of grafts for each fir species was as follows: Canaan (200), Fraser (200), Korean (100), momi (100), Nordmann (200), and Turkish (200). Nongrafted plants (controls) were maintained for comparisons in the greenhouse, and in field experiments. Grafting was done by three persons, taking care to have each person do about the same number of grafts for each species.

Experimental design. Grafted plants were held in plastic trays ( 13 bands per tray; 5 rows $\times 5$ columns; alternate bands empty on a checkerboard pattern), and placed on greenhouse benches where they remained during the 1999 growing season. Within a tray, plants were grafted by the same person. Trays containing grafts and nongrafted plants of each species were randomized across four greenhouse benches.

Measurements and data analysis. After the first growing season (Oct. 1999), the following measurements were made on each plant: 1 ) survival (alive $=1$, dead $=0$ ); 2 ) leader diameter $1 \mathrm{~cm}$ above the graft union, or $1 \mathrm{~cm}$ above the top whorl of branches for nongrafted plants, 3) leader elongation ( $\mathrm{cm})$, and 4) and leader orientation (orthotropic $=1$, plagiotropic or bent $=0$ ).

Analyses of variance (SAS Institute, 1989) were performed for seedlings and grafts for each trait using "species" and "tray(species)" as sources of variation. The "tray(species)" effects were used as the error terms in constructing the F tests for "species" effects. Analyses for binomial data were performed using tray means, resulting in a reduced model. These data were also transformed using the arcsin square root transformation, but nontransformed data are reported. For seedlings, differences between species means were tested using the Waller-Duncan $\mathrm{k}$ ratio $t$ test $(P \leq$ $0.05)$. For grafts, the Fraser fir seedlings were included in the analyses as a control, and compared with rootstock species using Dunnett's $t$ test $(P \leq 0.05)$.
Sites in the field. Three sites were selected: 1) Raleigh, N.C. (Wake Co.), 2) Alleghany Co., and 3) Laurel Springs, N.C. (Ashe Co.). The Wake Co. site, located on the Lake Wheeler Research Lab (N.C. State Univ.) in the central Piedmont, was $\approx 90 \mathrm{~m}$ above sea level, with an Appling fine sandy loam, and would not ordinarily be used for production of Abies Christmas trees. The Alleghany Co. site was located in the mountains of northwestern North Carolina (elevation $\approx 900 \mathrm{~m}$; soil = Watauga). Two years before initiation of this experiment, it was cleared by bulldozing. The first planting experienced heavy mortality largely due to phytophthora root rot. Our experiment was installed 2 years after the initial planting. The Ashe Co. site ( $2^{\text {nd }}$ rotation for Fraser fir) was located at the N.C. State Univ. Upper Mountain Research Station in Laurel Springs, N.C. (elevation $\approx 1000 \mathrm{~m}$; soil $=$ Watauga loam). The Alleghany and Ashe Co. sites were both within a region of heavy Fraser fir Christmas tree production.

Replicated experiments were established on each site, using seedling stock as well as grafted stock. There were 12 treatments, consisting of six Abies species (not grafted) and six rootstock species grafted with Fraser fir scions. A replication consisted of 12 contiguous planting spots, one for each of the 12 treatments. Tree spacing was $1.5 \mathrm{~m}$ in the row, and $1.5 \mathrm{~m}$ between rows. The Wake Co. site had 30 replications (reps), but owing to lack of plants, some treatments were missing from reps 19-30. All 25 reps were complete in Ashe Co., and the Alleghany site had 15 full reps out of 30 .

The Wake Co. site was planted on 29 Oct. 1999, using shovels and dibble bars. Alleghany and Ashe Co. sites were similarly planted in mid-Mar. 2000. Standard cultural practices were used on all sites. In addition, the Wake Co. site was also irrigated, as needed, during summer and fall.

Survival and leader elongation were measured at each site during March and April 2001. Separate analyses for grafted and nongrafted plants were carried out with GLM (SAS Inst., 1989), and means separated using the Waller-Duncan k ratio $t$ test $(P \leq 0.05)$.

\section{Results}

Seedlings in the greenhouse. Survival, leader length, and shoot orientation differed significantly $(P \leq 0.01)$ among species. Survival of nongrafted seedlings was $98 \%$, except for momi fir (95\%) (Table 1). Fraser and Korean fir seedlings had the largest stem diameters, with Canaan and momi fir intermediate, and Turkish and Nordmann fir the smallest. Canaan, momi, and Fraser fir had the longest leaders; Turkish and Nordmann fir the shortest. Of nongrafted seedlings, $93 \%$ to $98 \%$ had orthotropic shoots after one growing season.

Grafts in the greenhouse. Graft survival during the first year was $92 \%$ to $98 \%$ for all species except momi fir (83\%) (Table 1). Significant rootstock species effects occurred for stem diameter, but no Dunnett's test was performed because diameters were measured at different locations on the grafts and seedling controls.

The percentage of Fraser fir scions with orthotropic terminal shoots was $94 \%$ to $97 \%$ on Canaan, Fraser, Nordmann, and Turkish fir rootstocks-similar to that of nongrafted Fraser fir seedlings (98\%) (Table 1). However, Korean and momi fir rootstocks produced a significantly lower percentage of vertical terminal shoots ( $81 \%$ and $86 \%$, respectively), compared to controls. Fraser fir scions produced longer leaders on Canaan and momi fir rootstocks (10.8 and $10.4 \mathrm{~cm}$, respectively), compared to Fraser fir seedlings $(8.8 \mathrm{~cm})$ (Table 1).

Results in the field. First-year survival in Alleghany Co. was $53 \%$ to $80 \%$ except for momi fir (>95\%), and survival of grafts was slightly less than nongrafted controls. In Ashe Co., a better site, survival was $>98 \%$ except for Fraser fir grafts (79\%) (Table 2). In most cases, leader elongation of grafted scions was also greater than for nongrafted controls. This difference was negligible for grafted Fraser fir in Ashe, but significant in Alleghany Co.

In Wake County, first-year survival of momi fir, Nordmann fir, and Turkish fir was $70 \%$ to $87 \%$ both for grafted and nongrafted plants (Table 2). Only $10 \%$ of the Fraser firs survived the first year, compared to $23 \%$ to $27 \%$ of the Korean and Canaan fir. In general, leader elongation was greater for grafted scions than for nongrafted controls, even for Fraser fir.

\section{Discussion}

This is a long-term experiment involving a preparatory phase (acquisition and growth of containerized stock plants), a greenhouse phase (grafting + one growing season), and a field phase (replicated studies on three sites). Despite some weaknesses, there are several useful and valid conclusions.

Fraser fir was easily grafted onto rootstocks of other Abies species, and survival on all rootstocks except momi fir was $\geq 92 \%$ during the first year in the greenhouse (Table 1). Reduced survival for momi fir rootstocks probably resulted because many plants were small and more difficult to graft. Despite that, survival of momi fir was among the highest observed during the first year in the field (Table 2).

In the greenhouse, rootstock species affected traits of Fraser fir scions, but not the same for all species (Table 1). A positive effect was that Canaan fir rootstocks increased leader length of Fraser fir scions, compared to nongrafted Fraser fir seedlings. A negative result was that a lower percentage of leaders were vertical (orthotropic) on momi fir rootstocks.

Although size and vigor of the rootstock can influence subsequent growth and morphology of scions (Copes, 1980), there was no clear evidence of that in this study, at the species level. For example, Canaan, Fraser, and Korean fir rootstocks were initially the tallest prior to grafting, yet first-year leader elongation of Fraser fir scions on those 
Table 1. First-year growth for six greenhouse-grown Abies species: 1) nongrafted seedlings, and 2) grafted with Fraser fir scions.

\begin{tabular}{|c|c|c|c|c|c|c|c|c|c|c|c|c|}
\hline \multirow{2}{*}{$\begin{array}{l}\text { Growth } \\
\text { index }\end{array}$} & \multicolumn{6}{|c|}{ Seedlings $^{z}$} & \multicolumn{6}{|c|}{ Grafts (Fraser fir scion) ${ }^{z}$} \\
\hline & Can & Fra & Kor & Mom & Nor & Tur & Can & Fra & Kor & Mom & Nor & Tur \\
\hline Survival (\%) & $98 \mathrm{a}^{\mathrm{y}}$ & $98 \mathrm{a}$ & $98 \mathrm{a}$ & $95 \mathrm{~b}$ & $98 \mathrm{a}$ & $98 \mathrm{a}$ & 92 & 98 & 94 & \begin{tabular}{|l|}
83 \\
\end{tabular} & 97 & 95 \\
\hline Diameter $(\mathrm{mm})^{\mathrm{x}}$ & $4.5 \mathrm{bc}$ & $4.9 \mathrm{a}$ & $4.9 \mathrm{ab}$ & $4.4 \mathrm{c}$ & $3.4 \mathrm{~d}$ & $3.7 \mathrm{~d}$ & 7.6 & 6.8 & 7.2 & 7.1 & 7.3 & 7.2 \\
\hline Leader $(\mathrm{cm})^{\mathrm{w}}$ & $11.5 \mathrm{a}$ & $8.8 \mathrm{~b}$ & $6.7 \mathrm{c}$ & $8.9 \mathrm{~b}$ & $2.8 \mathrm{~d}$ & $3.7 \mathrm{~d}$ & 10.8 & 9.3 & 7.8 & 10.4 & 9.3 & 9.4 \\
\hline Shoot orientation ${ }^{v}$ & $97 \mathrm{ab}$ & $98 \mathrm{a}$ & $93 \mathrm{~b}$ & $93 \mathrm{~b}$ & $96 \mathrm{ab}$ & 98 a & 95 & 97 & 81 & 86 & 96 & 94 \\
\hline
\end{tabular}

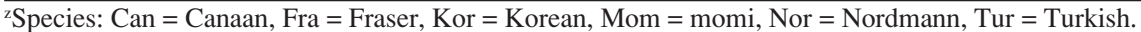

${ }^{y}$ Seedling species followed by the same letter are not significantly different; Waller-Duncan k ratio $t$ test $(P \leq 0.05)$. Boxes: grafts were significantly different from Fraser fir seedling controls according to Dunnett's $t$ test $(P \leq 0.05)$. No Dunnett's test was conducted for diameter (see text).

${ }^{x}$ Diameter of leader (two directions) $1 \mathrm{~cm}$ above the top whorl of branches (nongrafted); above union (grafted).

${ }^{w}$ New leader from the scion on grafted plants; natural leader on nongrafted plants.

vPercentage of leaders that were vertical and straight (orthotropic; no abnormal curvature).

Table 2. First-year survival and growth of six Abies species in the piedmont and mountains of North Carolina: 1) nongrafted seedlings, and 2) grafted with Fraser fir scions.

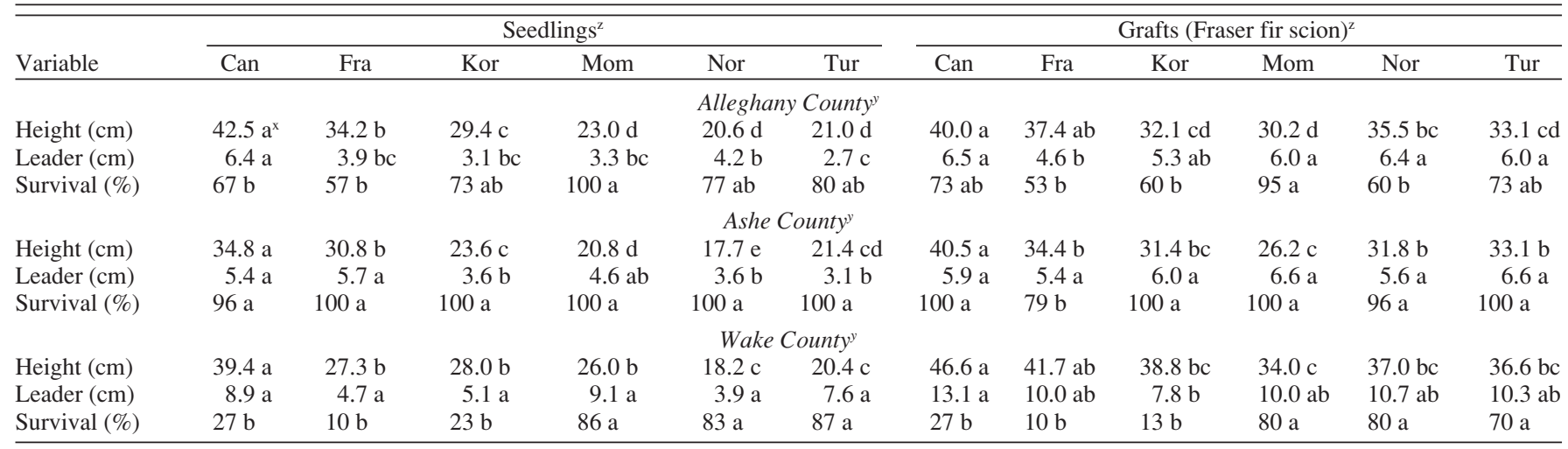

${ }^{\mathrm{z} S p e c i e s}$ : Can = Canaan, Fra $=$ Fraser, Kor $=$ Korean, Mom $=$ momi, Nor $=$ Nordmann, Tur $=$ Turkish.

${ }^{y}$ Mountains = Alleghany Co. and Ashe Co.; Piedmont $=$ Wake Co.

${ }^{\mathrm{x}}$ Means were separated within groups (nongrafted or grafted) using Waller-Duncan k ratio $t$ test $(P \leq 0.05)$.

rootstocks was not obviously different from that of momi, Turkish, and Nordmann fir rootstocks (Table 1). In the greenhouse, shoot elongation of Fraser fir was similar on grafted plants and nongrafted controls, indicating that the grafting procedure itself did not adversely affect growth the first year. In the field, however, results were somewhat unexpected, given that leader elongation of Fraser fir grafts was greater on two of the three sites, compared to nongrafted controls (Table 2). The difference in leader elongation, for which we have no explanation, was $>100 \%$ on the Wake County site. In addition, elongation of Fraser fir scions grafted onto other Abies species, in most cases, was greater than the leader elongation of nongrafted controls of the same species (Table 2).

As expected, most of the Fraser firs (90\%) died the first year in the field at the piedmont site in Wake County. In North Carolina, people have long debated why Fraser fir survives and grows poorly on piedmont and coastal plain sites. Earlier thinking was that the species could not withstand high air and soil temperatures during the summer. However, research and experience has shown that Fraser fir can tolerate warm temperatures in greenhouses and soilless mixes (Hinesley, 1981), especially if it experiences cool nights. In a second hypothesis, high soil and air temperatures, combined with extreme susceptibility of Fraser fir to phytophthora root rot, creates conditions that usually result in early mortality under field conditions. High temperatures, when combined with warm nights, are stressful to Fraser fir, and greatly reduce growth (Hinesley, 1981). In addition, warm soil temperatures favor the pathogen, particularly when combined with moist or wet soils during the growing season (Reynolds et al., 1985). This hypothesis was one motivation for embarking on research to identify Abies species with more resistance to root rot than Fraser fir (Benson et al., 1998a, 1998b; Hinesley et al., 2000).

Survival of various Abies species on the Wake County site mirrored results obtained with controlled inoculations of Abies seedlings with Phytophthora cinnamomi (Benson et al., 1998a, 1998b; Hinesley et al., 2000). In those studies, Fraser fir died quickly, followed by slower mortality of other species. Among the species tested, momi fir was most resistant, followed by Turkish and Nordmann fir. In the current experiments, only $10 \%$ of the Fraser fir survived the first year in the field in Wake County. In contrast, survival of momi fir, Turkish fir, and Nordmann fir transplants was $83 \%$ to $87 \%$, compared to $70 \%$ to $80 \%$ for grafted plants. No attempt was made to isolate pathogens from roots.

The Alleghany and Ashe County sites had similar climate and elevation, but the Alleghany site was probably a better indicator of potential rootstock differences under adverse conditions. On the Alleghany site, $53 \%$ of the Fraser fir grafts survived the first year, compared to $95 \%$ for momi fir, and $73 \%$ for Canaan fir and Turkish fir (Table 2). On the Ashe site, survival was $>96 \%$ except for Fraser fir grafts (79\%), but we have no explanation for this difference.

In these experiments, grafting success was high, and first-year survival in the field was good enough to warrant further investigation. Observations will continue to determine longterm performance of grafted and nongrafted plants of various Abies species. Grafting is biologically feasible, but the economic feasibility remains to be determined. Results offer hope that suitable rootstocks can be utilized to successfully introduce and grow Abies Christmas trees on sites generally regarded as too warm for Fraser fir. In addition, it might also allow continued use of sites already affected by phytophthora root rot in the traditional production areas at higher elevations in the mountains of North Carolina. Finally, cloning exceptional Fraser fir Christmas trees by grafting might be justified if there were sufficient improvement in the growth rate and quality of resulting plants.

\section{Literature Cited}

Benson, D.M. and L.F. Grand. 2000. Incidence of phytophthora root rot of Fraser fir in North Carolina and sensitivity of isolates of Phytophthora cinnamomi to metalaxyl. Plant Dis. 84:661-664.

Benson, D.M., L.E. Hinesley, J. Frampton, and K.C. Parker. 1998a. Evaluation of six Abies spp. to phytophthora root rot caused by Phytophthora cinnamomi. Biol. and Cultural Tests for Control of Plant Dis. 13:57.

Benson, D.M., L.E. Hinesley, J. Frampton, and K.C. Parker. 1998b. Evaluation of Canaan seed sources 


\section{Propagation \& Tissue Culture}

for resistance to phytophthora root rot caused by Phytophthora cinnamomi. Biol. and Cultural Tests for Control of Plant Dis. 13:58.

Copes, D.L. 1980. Effect of rootstock vigor on leader elongation, branch growth, and plagiotropism in 4- and 8-year-old Douglas-fir grafts. USDA, For. Serv. Tree Planters' Notes 31(4):11-14.

Hartman, H.T., D.E. Kester, and F.T. Davies, Jr. 1990. Plant propagation principles and practices. Prentice Hall, Englewood Cliffs, N.J.

Hinesley, L.E. 1981. Initial growth of Fraser fir seedlings at different day/night temperatures. For. Sci. 27:545-550.
Hinesley, L.E. 1985. Effect of transplanting time on growth and development of Fraser fir seedlings. HortScience 21:65-66.

Hinesley, L.E., K.C. Parker, and D.M. Benson. 2000. Evaluation of seedlings of Fraser, momi, and Siberian fir for resistance to Phytophthora cinnamomi. HortScience 35:87-88.

Reynolds, K.M., D.M. Benson, and R.I. Bruck. 1985. Epidemiology of Phytophthora root rot of Fraser fir: Root colonization and inoculum production. Phytopathology 75:1004-1009.

SAS Institute. 1989. SAS/STAT user's guide. Version $6,4^{\text {th }}$ ed. SAS Inst., Cary, N.C.

Thor, E., R.T. Britt, J. Sharp, and J.A. Cutlett. 1962.
Christmas tree production and marketing in Eas Tennessee. Univ. of Tennessee Agr. Ext. Serv. Circ. 589, Knoxville.

Tompkins, D. 1989. Grafting noble fir: a 16-year experiment. Pacific Northwest Christmas Tree Assn., Salem, Ore. Lookout 22(3):10-12, 1617.

Torbet, J.L. and T.J. Nichols. 1991. Species selection, p. 25-32. In: J.E. Johnson (ed.). Christmas tree production manual. Virginia Polytechnic Inst. State Univ., Blacksburg. Pub. 420-075.

Williams, G. 1995. Field grafting of conifers for Christmas tree seed orchards. Proc. Intl. Plant Prop. Soc. 44:557-558. 